\title{
Linear scleroderma en coup the sabre, progressive facial hemiatrophy and Rasmussen encephalitis : a single disease spectrum?
}

\author{
M Morren ${ }^{1 *}$, C Despontin $^{2}$, C Wouters $^{3}$ \\ From 18th Pediatric Rheumatology European Society (PReS) Congress \\ Bruges, Belgium. 14-18 September 2011
}

\section{Background}

Progressive hemifacial atrophy (PFH) and linear scleroderma en coup de sabre (LSCS) may be accompanied by neurologic symptoms and other extra-cutaneous manifestations.

\section{Aim}

To investigate and compare clinical/immune characteristics of patients with LSCS and PFH.

\section{Methods}

Retrospective study of 12 patients presenting at 2 pediatric dermatology clinics with linear scleroderma and/or hemifacial atrophy

\section{Results}

9 patients presented with LSCS, followed in 5 of them by progressive hemifacial atrophy (PFH) within 2 years.
3 patients presented with $\mathrm{PFH}$, all 3 had additional scleroderma lesions. Their median(range) age at presentation was 8(4-17)yrs.

Extracutaneous manifestations were equally found in LSCS and PFH+LSCS patients. They comprised asymmetry of tooth arches/missing teeth(1), ophthalmologic problems (eyelid ptosis, enophtalmia, bilateral anterior uveitis and renal papillary asymmetry)(4), epileptic seizures with hyperintense signals on MRI and hypoperfusion on SPECT in 1 LSCS (fig) and 1 PFH patient, severe migraine attacks(2), polyarthritis(2), vitiligo(1), celiac disease(1).

ANA were found in 3 LSCS, $2 \mathrm{PFH}+\mathrm{LSCS}$ patients. Distinct oligoclonal IgG bands were found in CSF (not in blood) in patients with PFH and seizures. A skin biopsy in a PFH lesion showed fibrosis associated with a lymphocytic infiltrate, IgM and IgG deposits. A brain biopsy in one PFH patient with epilepsy was consistent with Rasmussen encephalitis.
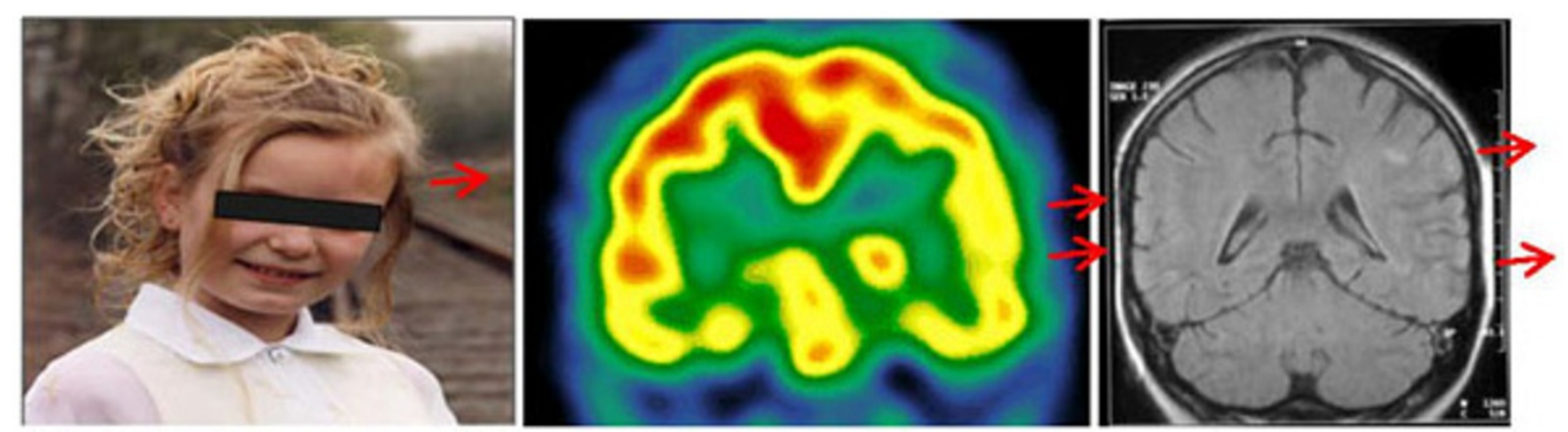

Figure 1

'Dept of Pediatric Dermatology, Leuven University Hospital, Belgium

Full list of author information is available at the end of the article

(C) 2011 Morren et al; licensee BioMed Central Ltd. This is an open access article distributed under the terms of the Creative Commons 
In patients with severe skin +- neurological lesions, treatment with steroids/high-dose MTX resulted in improvement/stabilization of clinical and MRI abnormalities

\section{Conclusion}

Our case series endorses the concept of a single disease spectrum encompassing LSCS and PFH, with a common immune-inflammatory pathogenesis. A possible relationship with RE is suggested as well.

\section{Author details}

${ }^{1}$ Dept of Pediatric Dermatology, Leuven University Hospital, Belgium. ${ }^{2}$ Dept of Pediatric Dermatology, Children's Hospital Luxembourg. ${ }^{3}$ Pediatric Rheumatology, Leuven University Hospital, Belgium.

Published: 14 September 2011

Cite this article as: Morren et al:: Linear scleroderma en coup the sabre, progressive facial hemiatrophy and Rasmussen encephalitis : a single disease spectrum? Pediatric Rheumatology 2011 9(Suppl 1):P79.

Submit your next manuscript to BioMed Central and take full advantage of:

- Convenient online submission

- Thorough peer review

- No space constraints or color figure charges

- Immediate publication on acceptance

- Inclusion in PubMed, CAS, Scopus and Google Scholar

- Research which is freely available for redistribution

Submit your manuscript at www.biomedcentral.com/submit 